DANMARKS GEOLOGISKE UNDERS $\oslash G E L S E$

III. Række. Nr. 41

Geological Survey of Denmark . III. Series . No. 41

\title{
Cyclogram technique for geological mapping of borehole data
}

By

Lars Jørgen Andersen

Cirkeldiagram-teknik for geologisk kortlægning af boredata

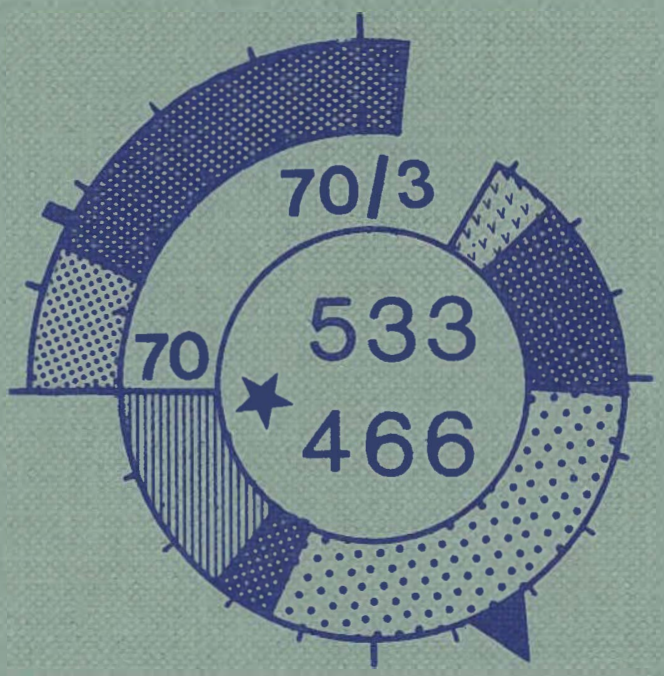

I kommission hos C. A. Reitzels Forlag . Kobenhavn 1973 
DANMARKS GEOLOGISKE UNDERSØGELSE

III. RÆKKE. NR. 41

Geological Survey of Denmark. III. Series. No. 41

\title{
Cyclogram technique for geological mapping of borehole data
}

\author{
By \\ Lars Jørgen Andersen \\ Cirkeldiagram-teknik for geologisk \\ kortlægning af boredata
}

I kommission hos

C. A. REITZELS FORLAG

København 1973 
D. G. U. III rk. nr. 41

er sat med Monotype Times

og trykt i 2200 eksemplarer

hos Andelsbogtrykkeriet i Odense

Klicheerne er fremstillet

af Tutein \& Koch

Bogen er trykt på ekstraglittet $605,125 \mathrm{~g}$

fra a/s De forenede Papirfabrikker

ISBN 8742106255

With a hydrogeological map of Northeast Zealand Med et hydrogeologisk kort over Nordøstsjælland 


\section{CONTENTS}

page

Abstract . . . . . . . . . . . . . . . . . . . . . . . . . . 5

Introduction . . . . . . . . . . . . . . . . . . . . . . . . . 7

Principle of the method . . . . . . . . . . . . . . . . . . . . . 7

Construction of the cyclogram . . . . . . . . . . . . . . . . . . . . 8

Interpreted Cyclogram-well-record-maps . . . . . . . . . . . . . 9

Discussion of the method . . . . . . . . . . . . . . . . . . . . 9

Conclusions . . . . . . . . . . . . . . . . . . . . . . . 10

Acknowledgements . . . . . . . . . . . . . . . . . . . . . . . 11

\section{INDHOLD}

Indledning

Metodens princip . . . . . . . . . . . . . . . . . . . . . . . . 12

Konstruktion af cirkeldiagramprofilet . . . . . . . . . . . . . . . 13

Fortolkede cirkeldiagramprofil-kort . . . . . . . . . . . . . . . . 14

Diskussion af metoden. . . . . . . . . . . . . . . . . . . . . . 14

Konklusion . . . . . . . . . . . . . . . . . . . . . . . . . . 15

Efterskrift. . . . . . . . . . . . . . . . . . 15 


\section{ILLUSTRATIONS}

Figures, figurer:

page, side

Fig. 1. Legend for the well-record-cyclogram . . . . . . . . . . 17

Signaturforklaring for cirkeldiagramprofilet . . . . . . . . 17

- 2. Preprinted cyclograms. . . . . . . . . . . . . . . . 18

Fortrykte cirkeldiagrammer . . . . . . . . . . . . . . 18

- 3. Form for well-record data . . . . . . . . . . . . . . . 19

Blanket til boredata. . . . . . . . . . . . . . . . . . 19

- 4. The template. . . . . . . . . . . . . . . 20

Drejeskabelonen . . . . . . . . . . . . . . . . . 20

- 5-16. Example of construction of a well-record-cyclogram. . . 22-25

Eksempel på konstruktion af et cirkeldiagramprofil. . . . 22-25

Maps, kort:

Hydrogeological map of Northeast Zealand

Scale 1:40.000. (Enclosure).

Hydrogeologisk kort over Nordostsjalland

Målestok 1:40.000. (Bilag). 


\begin{abstract}
This paper describes the principles of a new method for three-dimensional mapping of geological basic data from boreholes and wells. This method is developed by the Geological Survey of Denmark and uses cyclograms for graphical illustration of borehole records instead of bar diagrams.

The procedure and the technical tools for construction of the cyclogram and the map are described. Advantages and disadvantages of the method compared with other mapping methods are discussed.

For illustration of the method a map of about 350 sq. $\mathrm{km}$ with more than 500 well-record-cyclograms is enclosed.
\end{abstract}




\section{CYCLOGRAM TECHNIQUE FOR GEOLOGICAL MAPPING OF BOREHOLE DATA}

\section{INTRODUCTION}

The need for overview of the large number of well records and borehole data which are available in the Well Record Department of the Geological Survey of Denmark has led to the development of this method for geological mapping of borehole data.

The first attempt of this mapping technique was done in 1967 in connection with a hydrogeological investigation for the Sønderborg municipal water supply. Since that time the method has been refined, and tools and techniques for a simple construction of cyclograms have been designed. The maps have been used with great success in several areas of Denmark, such as Hirtshals, Svendborg, Fredericia, Esbjerg, Horsens and Northeast Zealand.

The enclosed map, for illustrating the method of mapping, has been compiled by the author based on data in the Well Record Department of the Geological Survey of Denmark, as an enclosure to the report from the SØHUND-commission: Vandbehov og vandindvindingsmuligheder i Nordøstsjælland, København 1973 (Water demand and groundwater availability in Northeast Zealand, Copenhagen, 1973).

\section{PRINCIPLE OF THE METHOD}

By this method the well record or borehole data, such as encountered formations, their contacts and some hydrogeological and technical data, are shown graphically in a cyclogram instead of a bar diagram as usually is done, see fig. 1 . The cyclogram consists of a number of concentric circles. Each circle embraces 100 metres of the penetrated sequence, and under Danish elevation conditions the interior circle, circle No. 1, fig. 1, embraces elevations from $100 \mathrm{~m}$ above sea level, at 9 o'clock, moving clockwise around with increasing depth to the sea level, at 9 o'clock again. Elevations below sea level are indicated in the next following outer circle, circle No. 2, fig. 1, which embraces the strata from sea level down to $100 \mathrm{~m}$ below sea level, and so on.

In each cyclogram the geological formations in the different parts of the section may be illustrated by symbols or colours as usual. Furthermore parameters such as the capacity of the well, groundwater level and screened and cased 
intervals may be indicated by symbols or digits as shown in fig. 1 and in the legend of the enclosed map.

Under other topographic conditions with greater differences in elevation each circle may embrace a thicker sequence even up to $1000 \mathrm{~m}$. However, this would correspondingly reduce the detail.

\section{CONSTRUCTION OF THE CYCLOGRAM}

For a simple construction of the cyclograms a practice has been developed which make it possible to construct a well record cyclogram within a few minutes by help of the following tools:

1. Sheets of adhesive transparent paper with preprinted cyclograms, fig. 2.

2. An abbreviated description of the well record with the elevation of the ground surface at the well site (available data), fig. 3 .

3. A circular template the periphery of which is graduated in 100 parts, each corresponding to $1 \mathrm{~m}$ of depth, fig. 4 . In the centre of the template there is a hole for placing a pin around which the template can be turned. In the template the quadrant between 0 and 25 metres is cut out. In this way it is possible to draw radial lines corresponding to the geological contacts and other parameters. In the template at different distances from the centre holes are made by means of which cyclograms may be constructed if no preprints of these are available. Furthermore, special holes are present for construction of the screened intervals in different circles. The holes and the slot in the template are constructed for a pen diameter of $0.2 \mathrm{~mm}$.

To complete the description of the template it should be mentioned that about $1 \mathrm{~mm}$ of the underside of the template is cut away except for $2 \mathrm{~mm}$ around the centre and $10 \mathrm{~mm}$ along the periphery, to prevent destroying of the drawing by the turning of the template.

4. Letraset adhesive symbols for the encountered geological information.

The cyclogram for each well or borehole is constructed by placing the template on the transparent paper with its centre in the centre of a preprinted cyclogram with a pin placed in the central hole down into the drawing table below. The zero line on the template is turned due west, or 9 o'clock. Just outside the template at the elevation of the ground surface at the well or borehole which has to be constructed a small mark is indicated on the cyclogram sheet, (the "surface mark"), and the template is turned so that zero on the template is just opposite this mark. A line is drawn along the zero line in the circle corresponding to the given elevation, indicating the ground surface. Construction of contact lines between the penetrated geological formations can now be done by turning the template clockwise until the number on the 
template corresponding to the contact depth is just opposite the "surface mark" and by drawing lines along the zero line of the template.

Water level, bottom of casing and screened intervals are indicated in the same way. When all contacts have been indicated the different symbols are placed on the cyclogram, and the construction of the cyclogram is finished, see the illustrations figs. 5-16.

By help of the template the well-record-cyclogram can be done without any computations in connection with the conversion of depths below ground surface to elevations due to the fact that the template works as a kind of sliderule.

When all well-record-cyclograms within the mapped area have been constructed the unused part of the preprinted cyclogram is cut away by help of a pair of scissors, the adhesive transparent film is removed from the back and the cyclogram is placed on a transparent map sheet in the neighbourhood of the well site.

During placing, care should be taken in respect to the orientation of the cyclogram on the map, so that sea level will be placed due west, or at 9 o'clock, and in respect to position, so that the mutual position of the cyclograms corresponds to the real position of the boreholes.

\section{INTERPRETED CYCLOGRAM-WELL-RECORD-MAPS}

As mentioned above the cyclogram-well-record-map itself is a basic map which can be used for all geological and hydrogeological purposes. At the Geological Survey of Denmark up till now this type of maps has been used for mapping the distribution of aquifers and their surrounding conditions. However, interpretations of different geological or hydrogeological parametres may be indicated on the map too, for instance contours of top of bedrock, groundwater level, direction of groundwater flow, groundwater divides etc., see the enclosed map. In this case the map changes from a basic-data map to an interpreted map. Moreover the area between the cyclograms on the map may be coloured according to the geological formation at the ground surface or according to the hydraulic properties of the aquifers.

\section{DISCUSSION OF THE METHOD}

This method has several advantages in relation to other methods of geological mapping. The most important one is that beds from different wells situated at the same elevation will be placed in the cyclogram in the same circle and in the same direction, i.e. at the same clock time. This arrangement regarding the orientation of the cyclograms makes correlation between borehole information in any direction very simple. No correlation lines need to be drawn, and 
this means that data from new wells can easily be added to the map as they become available without changing any of the earlier data.

This is not possible in the case of cross sections, due to the fact that by this method of graphical illustration correlation lines have to be drawn. If new data later become available, and the contacts between the different beds encountered do not coincide with the original correlation lines, new correlation lines have to be drawn, which means that most of the cross section has to be reconstructed. If cross sections are to be constructed the cyclogram map will show the most desirable direction for such a section.

Furthermore, the cyclogram-well-record-map gives not only detailed information of all penetrated layers thicker than 1 to 2 metres from each single borehole or well, but at the same time the compiled information from all the boreholes provides regional distribution of the encountered geological information in three dimensions.

The method can be used in all flat-land areas, and has a great advantage in glaciated regions, where the inhomogeneity of the deposits is high. The method is not convenient in areas or regions with large differences in elevation, since the cyclograms then have to contain several circles, which will reduce the possibilities of correlation between them.

Another disadvantage is that graphs from borehole logging are not easily constructed in relation to the cyclograms. One single graph could possibly be constructed; however, the construction seems to be complicated. This problem has not been attempted solved since in Denmark normally no well logs are available.

The datum level of course may be placed at any direction or clock time required. However, on the single map or on maps which should be correlated it has to be placed in the same direction. Furthermore the scale of each circle may be chosen arbitrarily.

\section{CONCLUSIONS}

The cyclogram-well-record-map gives the total amount of geological information in a three-dimensional survey on one single sheet of paper. It provides good opportunities for correlation between well records in any direction, and it gives detailed information for each single well record or borehole. It is easy to update when new data become available. It is a basic-data map with a low degree of interpretation. It satisfies the need for overview of the large number of well records on which all geological knowledge has to be based in a flat land as Denmark where the bedrock formation is covered by loose glacial formations. This method will be convenient for any flat land, but especially where the distribution of the geological formations has a high degree of arbitrariness and inhomogeneity, such as in glaciated regions. 


\section{ACKNOWLEDGEMENTS}

I gratefully acknowledge the geologists N. V. Jessen, B. BagGe and stud. scient. E. CLAuSEN for valuable ideas and help during the detailed design of the tools and the technique for construction of the cyclogram map. For careful construction of the cyclograms and for new ideas for the procedure of this construction I am indebted to the assistants A. FrANDSEN and H. CARSTENSEN. The drawing of the map except the cyclograms are done by the firm KEMP \& LAURITZEN and their staff, and the template is manufactured by the firm JUHLSCHMidT, Søborg. Typing of the manuscript is made by Mrs. I. Christensen. I bring all of these my best thanks for their work. 


\section{CIRKELDIAGRAM-TEKNIK FOR GEOLOGISK KORTLÆGNING AF BOREDATA}

\section{INDLEDNING}

Behovet for oversigt over det store antal af boreprofiler og boredata, som findes tilgængelig ved borearkivet ved Danmarks Geologiske Undersøgelse, førte til udviklingen af denne metode for geologisk kortlægning af boredata.

Det første forsøg på denne kortlægningsmetode blev gjort i 1967 i forbindelse med en hydrogeologisk undersøgelse for Sønderborg kommunale vandforsyning. Siden da er metoden blevet forbedret, og der er fremstillet hjælpemidler og udarbejdet procedure for en simpel og hurtig konstruktion af cirkeldiagramprofilerne. Korttypen er blevet benyttet med stor succes i adskillige områder af Danmark, f.eks. Hirtshals, Svendborg, Fredericia, Esbjerg, Horsens og Nordøstsjælland.

Det vedlagte kort for illustration af kortlægningsmetoden er udarbejdet af forfatteren på basis af data i Danmarks Geologiske Undersøgelse's borearkiv som bilag til SøHUND-udvalget's rapport: Vandbehov og vandindvindingsmuligheder i Nordøstsjælland, København 1973.

\section{METODENS PRINCIP}

Ved denne metode afbildes boredata fra den gennemborede dybde, laggrænser, visse hydrogeologiske parametre og tekniske data grafisk i et cirkeldiagram i stedet for i et søjleprofil, se fig. 1. Cirkeldiagrammet består af flere koncentriske cirkler. Hver cirkel indeholder $100 \mathrm{~m}$ boredybde, og under danske højdeforhold indeholder den indre cirkel, cirkel nr. 1, fig. 1, jordlagene fra $100 \mathrm{~m}$ over havets overflade (kl. 9.00) til $0 \mathrm{~m}$ over havets overflade, (tilbage til kl. 9.00), idet dybden vokser med uret. Jordlag beliggende under havets overflade er placeret i den næstfølgende ydre cirkel, cirkel nr. 2, fig. 1, som indeholder jordlagene beliggende fra havets overflade til $100 \mathrm{~m}$ under havets overflade. Jordlagene fra kote -100 til -200 m placeres i den næstfølgende cirkel, og så fremdeles.

I cirkeldiagrammet kan de forskellige geologiske aflejringer angives med symboler eller farver som sædvanligt. Endvidere kan parametre som boringens kapacitet, grundvandsspejl, filterinterval og bund af borerør angives med symboler eller tal, som vist på symbolforklaringen fig. 1. og på det vedlagte kort.

Under andre topografiske forhold med større forskelle i terrænhøjden eller 
større boredybder, kan hver cirkel indeholde en større lagmægtighed, f.eks. 1000 m. Dette kan naturligvis kun ske på bekostning af detaljer i boreprofilet.

\section{KONSTRUKTION AF CIRKELDIAGRAMPROFILET}

For at lette konstruktionen af cirkeldiagramprofilet er der udarbejdet en praksis, der gør det muligt at konstruere et cirkeldiagramprofil på få minutter ved hjælp af følgende hjælpemidler.

1. Ark med adhesiv transparent film med påtrykte cirkeldiagrammer, fig. 2 .

2. Et forkortet boreprofil med angivelse af terrænkoten ved boringen, fig. 3 .

3. En cirkulær drejeskabelon, hvis periferi er inddelt i 100 enheder, hver svarende til $1 \mathrm{~m}$ boredybde, fig. 4 . I centrum af skabelonen er der boret et hul for placering af en knappenål, omkring hvilken skabelonen kan drejes.

I cirkelskabelonen er de $90^{\circ}$ mellem 0 og 25 m skåret ud i området mellem skalaen og centrum. Derved bliver det muligt at trække radierende linier svarende til laggrænser og andre parametre. I forskellig afstand fra centrum er der anbragt huller ved hjælp af hvilke, cirkeldiagrammet kan konstrueres direkte på kortet i tilfælde af, at der ikke foreligger fortryk af disse. Endvidere er der placeret specielle huller og udskæringer for konstruktion af signatur for filter og vandstand.

Alle huller og udskæringer er konstrueret for en pennediameter på $0,2 \mathrm{~mm}$.

For en fuldstændigheds skyld skal det bemærkes, at ca. $1 \mathrm{~mm}$ af cirkelskabelonens underside er fjernet $\mathrm{i}$ området mellem $2 \mathrm{~mm}$ fra centrum og ca. $10 \mathrm{~mm}$ fra skabelonens periferi for at undgå udtværing af laggrænser m.v., når skabelonen drejes.

4. Letraset symboler for de forekommende geologiske aflejringer.

Det enkelte cirkeldiagram og profil konstrueres ved at dreje skabelonen. Centrum anbringes over centrum i det fortrykte cirkeldiagram, hvorefter en knappenål stikkes gennem centrum og ned i et passende blødt underlag. 0-linien på skabelonen anbringes stik vest eller k1. 9.00. Umiddelbart uden for cirkelskabelonen ved det tal, som angiver terrænkoten for boringen, anbringes et midlertidigt mærke, et "terræn-mærke", og cirkelskabelonen drejes, så dens 0-punkt står ud for "terræn-mærket”, og der trækkes en linie langs 0-linien igennem cirklen, som svarer til den givene terrænkote. Denne linie repræsenterer terrænoverfladen.

Dybderne for laggrænser mellem de forskellige lag i boringen kan nu indtegnes ved at dreje skabelonen, således at det tal på skabelonen, som svarer til den angivne dybde, anbringes ud for "terræn-mærket", hvorefter laggrænsen indtegnes. Grundvandstand og filterinterval kan indtegnes på tilsvarende måde.

Når alle laggrænser er indtegnet, anbringes de forskellige symboler i cirkel- 
diagrammet, og boringens cirkeldiagramprofil er færdigkonstrueret, se illustrationerne fig. 5-16. Ved hjælp af drejeskabelonen kan cirkeldiagramprofilet tegnes uden nogen omregning fra dybde under terræn til kote $\mathrm{m}$, idet drejeskabelonen samtidig fungerer som en "regnestok".

Når alle cirkeldiagramprofiler inden for det kortlagte område er konstrueret, bortklippes med en saks de ubenyttede dele af cirkeldiagrammerne, og den adhesive hinde med cirkeldiagramprofilet fjernes fra underlaget og anbringes på et transparent målfast kort nær borepunktet.

Ved placeringen af cirkeldiagramprofilet på kortet skal der tages to hensyn, for det første skal cirkeldiagramprofilets 0 -kote (kl. 9.00) placeres stik vest eller kl. 9.00, og for det andet skal cirkeldiagramprofilerne placeres således, at deres indbyrdes beliggenhed såvidt muligt svarer til boringernes indbyrdes beliggenhed.

\section{FORTOLKEDE CIRKELDIAGRAMPROFIL-KORT}

Cirkeldiagramprofil-kortet er et basisdatakort, som kan benyttes til alle geologiske og hydrogeologiske formål. Ved Danmarks Geologiske Undersøgelse har de indtil nu kun været benyttede for illustration af den rumlige udbredelse af grundvandsforekomster og deres omgivende lag.

Imidlertid kan forskellige geologiske eller geohydrologiske parametre tillige angives på kortet, hvorved det kun bliver et basiskort med hensyn til boreprofildata.

På vedlagte kort er bl.a. angivet kurver for prækvartæroverfladens højdeforhold, grundvandstanden fra prækvartære vandførende lag og fra vandførende lag i kvartæret, grundvandsstrømmens retning samt grundvandsskel for de respektive grundvandsforekomster.

En yderligere mulighed for at øge antallet af parametre på kortet foreligger, nemlig at udfylde området mellem cirkeldiagramprofilerne på kortet, enten $i$ henhold til de geologiske forhold i terrænniveau eller i henhold til de vandførende lags hydrauliske egenskaber.

\section{DISKUSSION AF METODEN}

Denne kortlægningsmetode har flere fordele fremfor eksisterende kortlægningsmetoder først og fremmest den, at lag fra forskellige boringer beliggende i samme kote i cirkeldiagramprofilet vil være at finde i samme cirkel og i samme retning (på samme klokkeslæt).

Dette forhold medfører, at korrelation mellem boringer i en hvilken som helst retning bliver en simpel sag. Det er unødvendigt at indtegne korrelationslinier. Dette medfører igen, at data fra nye boringer let vil kunne påføres kortet, efterhånden som de foreligger uden forandring af de tidligere indtegnede data. Dette er ikke muligt ved andre former for tværprofiler som følge af, at disse 
kræver korrelationslinier. Hvis nye data skal indføres, og laggrænserne i henhold til disse ikke falder sammen med de interpolerede korrelationslinier, hvilket sjældent vil være tilfældet, må tværprofilet rekonstrueres.

Hvis man endelig ønsker at konstruere tværprofiler, vil cirkeldiagramkortet kunne vise den mest hensigtsmæssige retning for sådanne.

Endvidere giver cirkeldiagramprofil-kortet ikke blot detailleret information om alle gennemborede jordlag med mægtighed over 1 à $2 \mathrm{~m}$ for hver enkel boring, men samtidig giver den samlede information fra alle boringer den regionale fordeling af de gennemborede formationer i tre-dimensional form.

Metoden er anvendelig for geologisk kortlægning af boredata i alle sletteområder specielt i nedisningsområder, hvor løse aflejringer dækker dybgrundsaflejringerne. Den er derimod mindre velegnet $i$ områder med store niveauforskelle, idet de enkelte cirkeldiagrammer da kommer til at indeholde mange cirkler, hvilket vil vanskeliggøre en hurtig korrelation boringerne imellem.

En anden ulempe ved metoden er, at kurver fra borehul-logs vanskeligt vil kunne konstrueres i forbindelse med cirkeldiagramprofilerne. En enkelt kurve vil formentlig kunne indføres, men dette spørgsmål er ikke løst, da borelogs normalt ikke foreligger fra danske vandboringer.

Kote 0 kan naturligvis placeres i en vilkårlig retning og cirkel. På samme kort eller kort, som skal sammenlignes må kote 0 imidlertid placeres i samme retning. Endvidere kan antallet af meter pr. cirkel vælges efter ønske.

\section{KONKLUSION}

Cirkeldiagramprofil-kort giver den størst mulige mængde af geologisk information i en tre-dimensional overskuelig form på et enkelt kort.

Det muliggør en hurtig og sikker korrelation mellem boringer i enhver retning, og det giver detaillerede oplysninger om hele lagfølgen i den enkelte boring.

Det er et basiskort med den mindst mulige fortolkning, og det er let at revidere, når nye boredata foreligger.

Det tilfredsstiller behovet for overblik over det store antal af boringer, som efterhånden foreligger, og på basis af hvilket praktisk taget al geologisk kortlægning må baseres i et nediset lavlandsområde som Danmark, hvor kvartære løsjordaflejringer dækker alle dybgrundsaflejringer.

Cirkeldiagramprofil-kort vil være velegnede for ethvert lav-eller sletteland uanset dets absolutte højdebeliggenhed specielt i områder, hvor de geologiske forhold udviser en høj grad af vilkårlighed og uregelmæssighed, som f.eks. nedisningsområder.

\section{EFTERSKRIFT}

Under udviklingen af denne kortlægningsmetode har jeg modtaget værdifuld hjælp og gode ideer ved udformningen af de benyttede hjælpemidler for frem- 
stillingen af cirkeldiagramprofil-kortet fra geologerne N. V. JEsSEN, B. BAGGE og stud. scient. E. Clausen.

For omhyggelig og hurtig konstruktion af cirkeldiagramprofilerne takker jeg assistenterne A. Frandsen og H. Carstensen.

Tegning af kortet udover cirkeldiagramprofilerne er udført af firmaet KEMP \& Lauritzen's tegnestue, og teksten er maskinskrevet af fru I. Christensen. Cirkelskabelonen er fremstillet af firmaet JuHL-Schmid, Søborg. Jeg takker alle for deres indsats. 


\section{FIGURES - FIGURER}

NUMBERS INDICATE DEPTHS IN METRES, IN CIRCLE NO, I ABOVE SEA LEVEL AND IN THE FOLLOWING OUTER CIRCLES BELOW SEA LEVEL

SITE OF WELL

WELL NUMBER

UPPER: DGU FILE No.

LOWER: WATERWORKS' NO.

YEAR OF DRILLING (1967)

SCREENED INTERVAL

(WITH NO,)

BotTOM OF CASING

GROUNDWATER LEVEL

CONTACT

GEOLOGICAL SYMBOL

YIELD IN $\mathrm{M}^{3} / \mathrm{H} /$ DRAWDROWN

GEOLOGICAL DESCRIPTION AVAILABLE
Circle No.1

Cirke1 nr.1
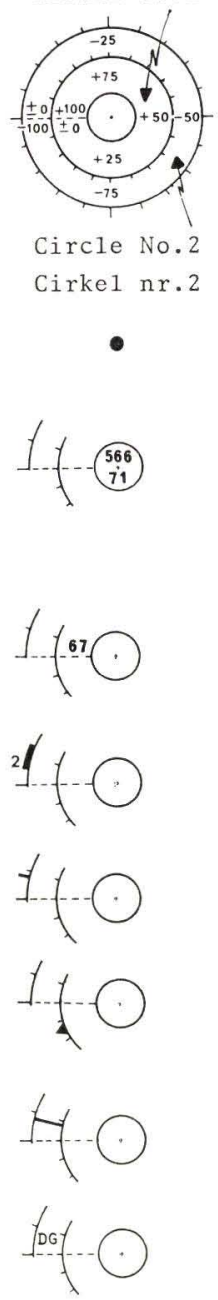

$37 / 5.8$

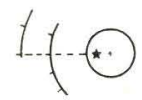

Fig. 1. Legend for the well-record-cyclogram.

Fig. 1. Symbolforklaring for cirkeldiagramprofilet.
BELIGGENHED AF BORING

TAL ANG IVER BOREDYBDE I METER, I CIRKEL NR, 1 OVER KOTE NUL OG I DE FØLGENDE YDRE CIRKLER UNDER KOTE NUL

BORENUMMER

ØVRE: DGU ARK.NR. Nedre: VandVERKETS NR,

BORINGENS UDFØRELSESAR (1967)

FILTERINTERVAL (MED NR.)

UNDERKANT AF BORERøR

GRUNDVANDSTAND

LAGGRENSE

JORDLAGSSYMBOL

YDELSE I $\mathrm{M}^{3} / \mathrm{H} / \mathrm{M}$ SENKNING

DGU-PRøVEBESKRIVELSE FORELIGGER 

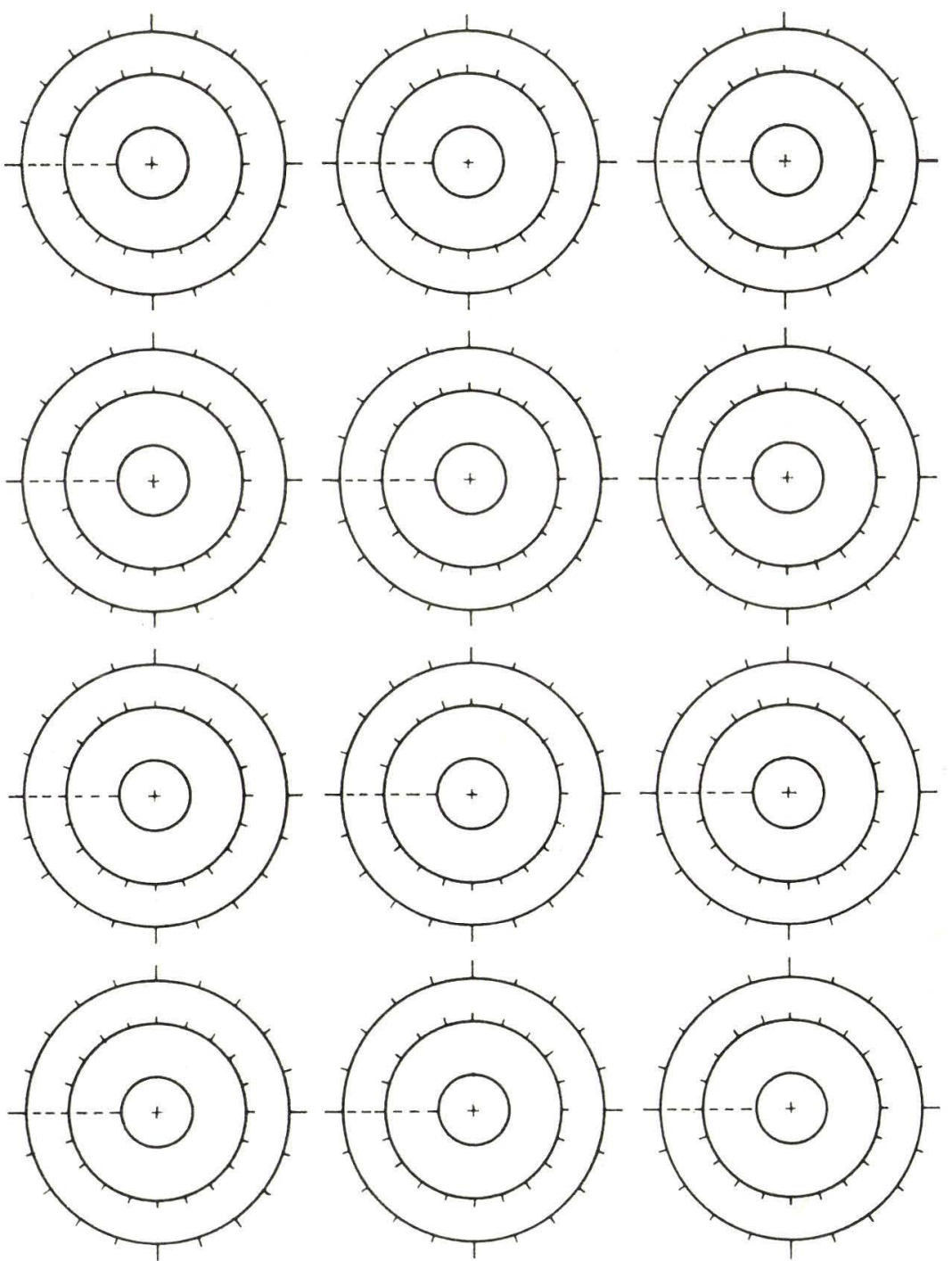

Fig. 2. Preprinted cyclograms on transparent adhesive film, used at the Geological Survey of Denmark (D.G.U.).

Fig. 2. Fortrykte cirkeldiagrammer på transparent, selvklabende film, benyttet ved Danmarks Geologiske Undersogelse (D.G.U.). 


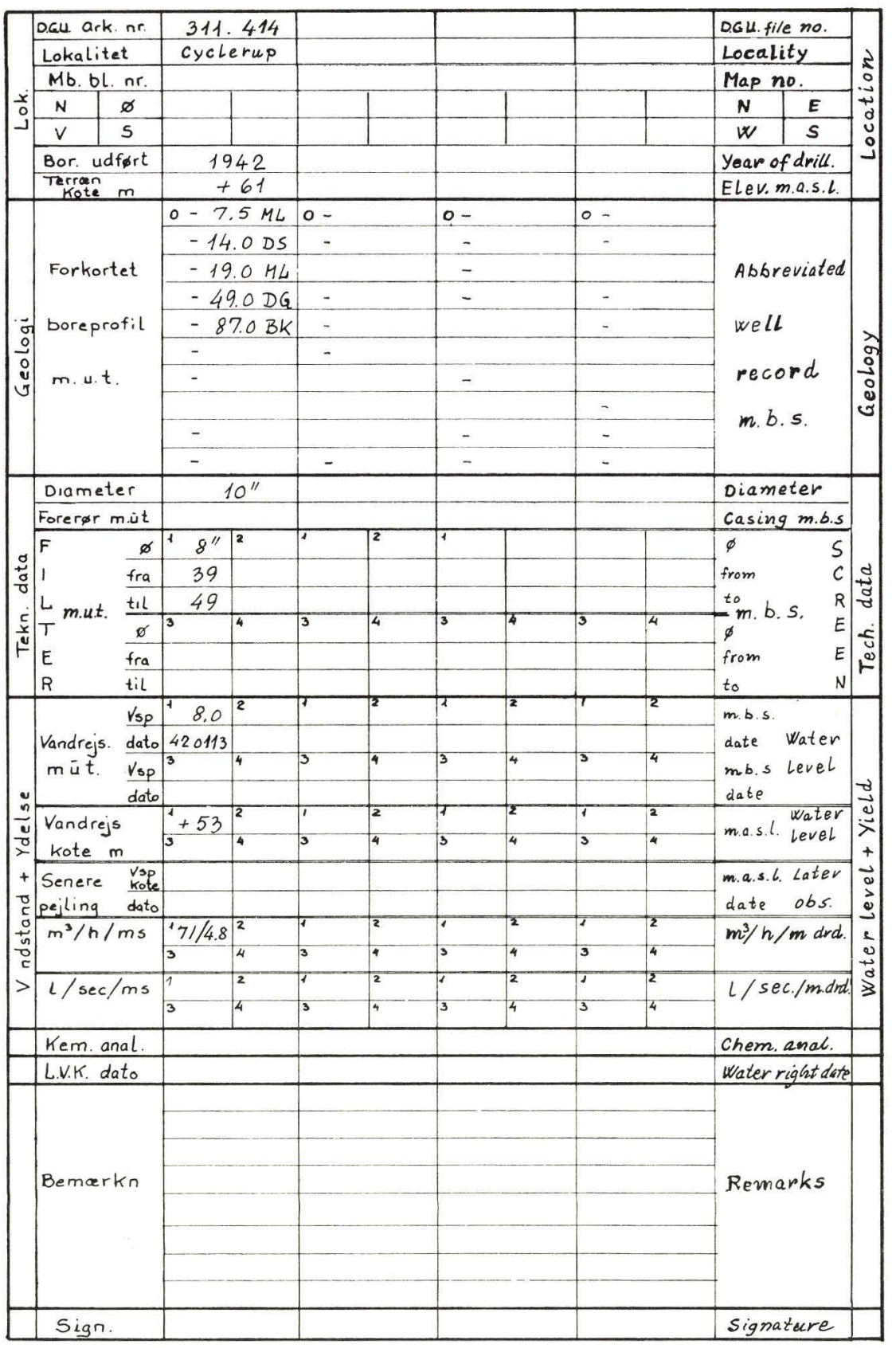

Fig. 3. Form for abbreviated well-record and selected data, used at the Geological Survey of Denmark (D.G.U.).

Fig. 3. Blanket til forkortet boreprofil og udvalgte data anvendt ved Danmarks Geologiske Undersogelse (D.G.U.). 

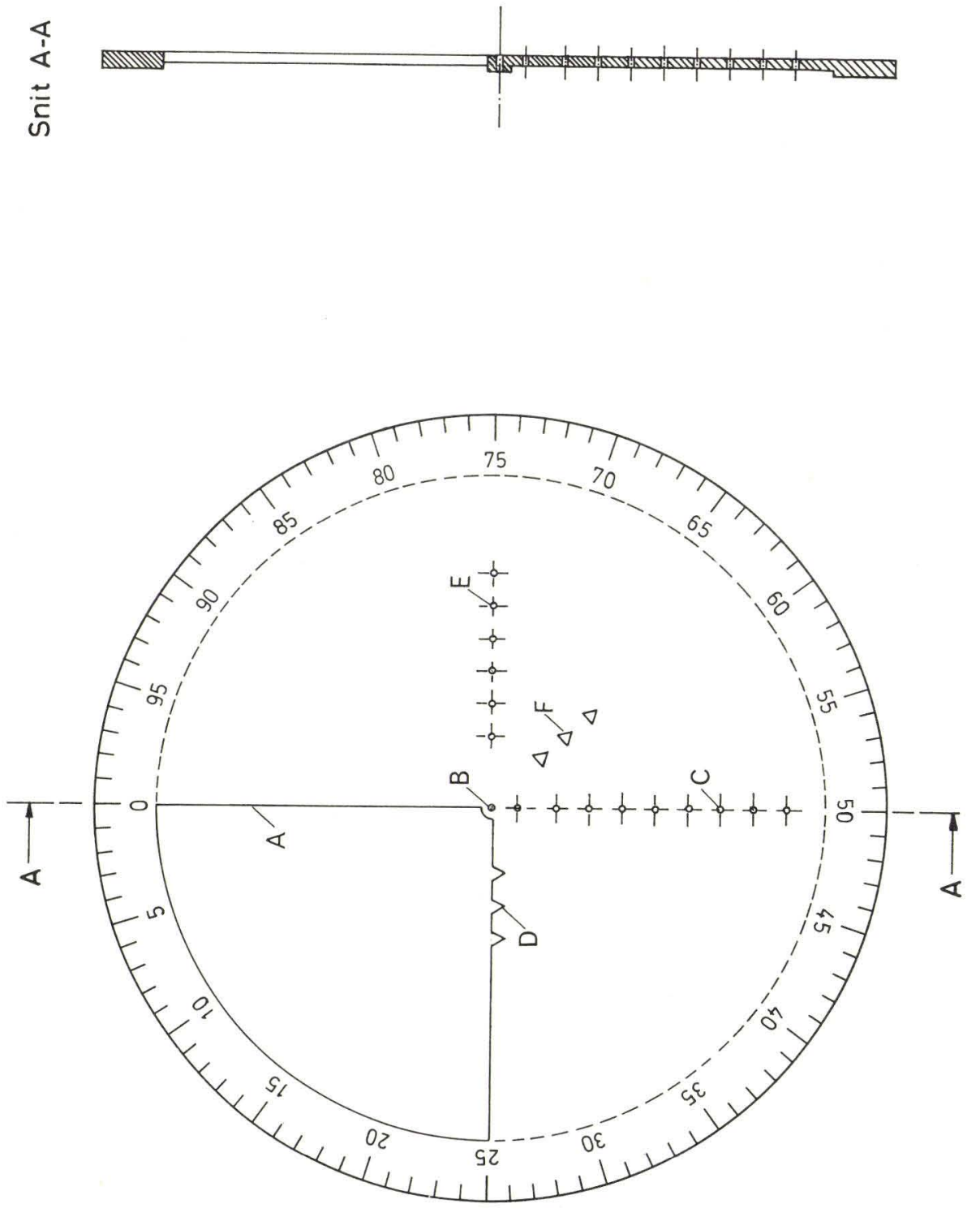

Fig. 4. 
Fig. 4. Template made of plexiglass for construction of well-record-cyclograms, the periphery of which is graduated in 100 parts, each corresponding to $1 \mathrm{~m}$ of penetrated depth. Cuts and perforations are constructed for a pen diameter of 0.2 millimetre.

Fig. 4. Drejeskabelon af plexiglas for konstruktion af cirkeldiagramprofiler med periferien inddelt $i 100$ dele hver svarende til $1 \mathrm{~m}$ boredybde. Udskaringer ag perforationer er kanstrueret for en pennediameter på $0,2 \mathrm{~mm}$.

A. 0-line, along which contacts and other levels are constructed and drawn in the cyclogram.

A. O-linie, langs hvilken laggranser og andre niveauer fastlagges og indtegnes $i$ cirkeldiagrammet.

B. Centre for placing a pin around which the template may be turned.

B. Centralt hul for placering af en nål, amkring hvilken skabelonen kan drejes.

C. Perforations (holes) for construction of the respective circles by using the template as a pair of compasses.

C. Perforationer (huller) for konstruktion af diverse cirkler, idet drejeskabelonen benyttes som passer.

D. Cuts for construction of circles in case other pen sizes than the recommended one are used (subsidiary pencil or ball pen).

D. Udskaringer for konstruktion af cirkler i tilfalde af, at der anvendes en anden pennediameter end den foreskrevne (subsidiart blyant eller kuglepen).

E. Perforations for construction of symbols for screened intervals.

E. Perforationer (huller) for konstruktion af filtersignatur.

F. Cuts for construction of symbols for groundwater level.

F. Udskaring for konstruktion af vandstandssignatur. 

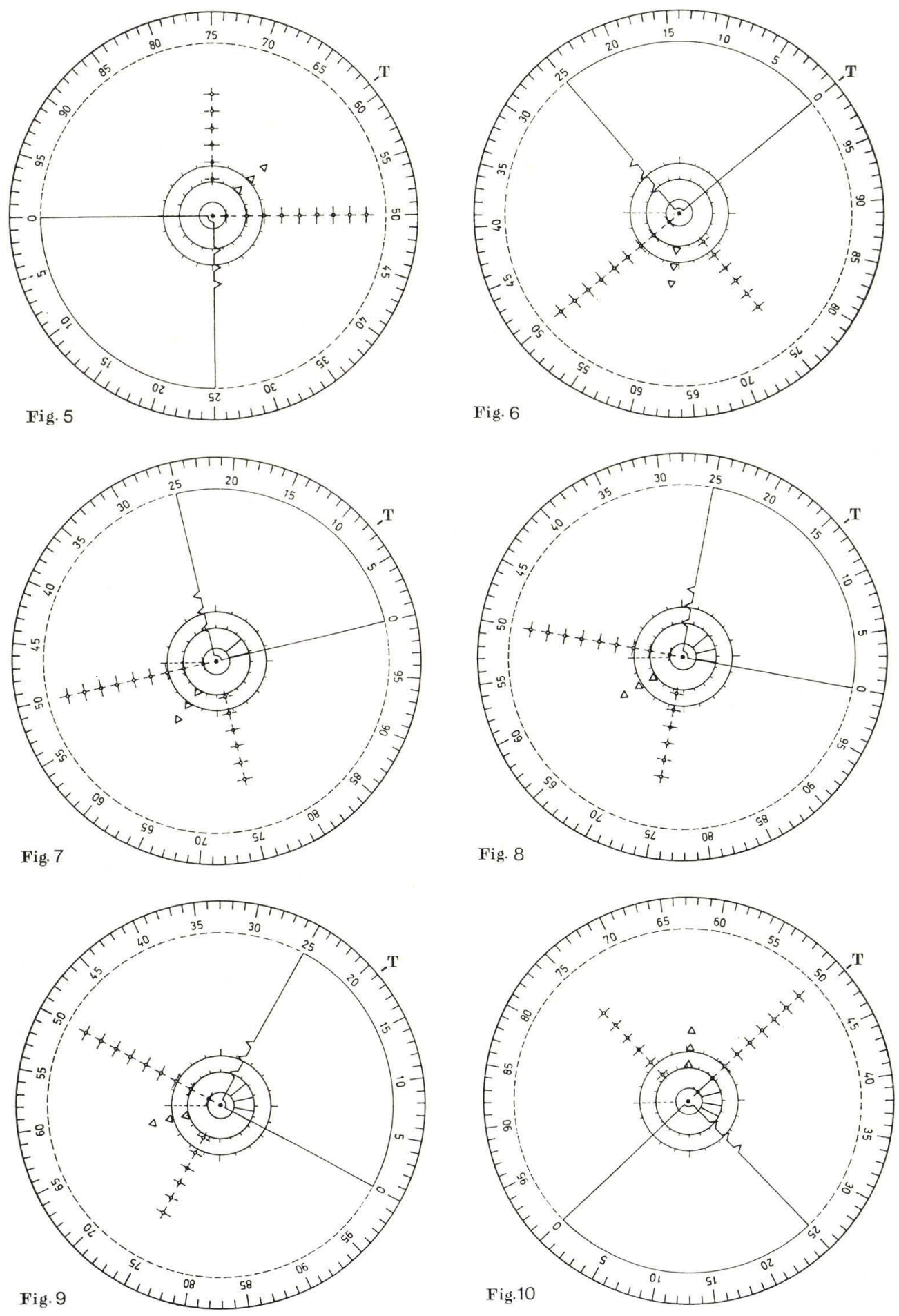
Based on the well-log in the table fig. 3 the well-record-cyclogram is constructed as shown in the figures $5-16$.

På basis af boreprofilet i skemaet fig. 3 konstrueres cirkeldiagramprofilet som vist i figurerne $5-16$.

Fig. 5. The "surface point" ( $\mathrm{T}$ in figs. 5-14) is found by turning the template's zero-point to $9 \mathrm{o}$ 'clock. This point is indicated on the paper outside the template at the number equal to the elevation of the ground surface, in this case $+61 \mathrm{~m}$.

Fig. 5. "Terranpunktet" (T på fig. 5-14) findes ved at anbringe skabelonens 0-punkt kl. 9.00. Dette punkt markeres ved et marke på underlaget uden for skabelonen ud for det tal, som er lig med borestedets terrankote, her $+61 \mathrm{~m}$.

Fig. 6. The 0-point of the template is turned to opposite the "surface point", and the contact of the ground surface is drawn along the 0 -line of the template in circle No. 1.

Fig. 6. Skabelonens 0-punkt drejes ud for "terranpunktet", og terrænlaggræensen trækkes langs skabelonens 0-linie i cirkel $n r .1$.

Fig. 7. The depth of the contact $7.5 \mathrm{~m}$ below surface is now placed opposite to the "surface point", and this contact is drawn in circle No. 1.

Fig. 7. Dybden til laggransen 7,5 $\mathrm{m}$ under terran drejes ud for "terranpunktet", og denne laggranse trakkes langs 0-linien i cirkel $\mathrm{nr}$. 1 som ovenfor.

Fig. 8 . The contact at $14 \mathrm{~m}$ below ground surface is drawn as above.

Fig. 8. Laggransen på $14 \mathrm{~m}$ placeres som ovenfor.

Fig. 9. The contact at $19 \mathrm{~m}$ is drawn as above.

Fig. 9. Laggransen på $19 \mathrm{~m}$ placeres som ovenfor.

Fig. 10. The contact at $49 \mathrm{~m}$ is drawn as above.

Fig. 10. Laggransen på $49 \mathrm{~m}$ placeres som ovenfor. 

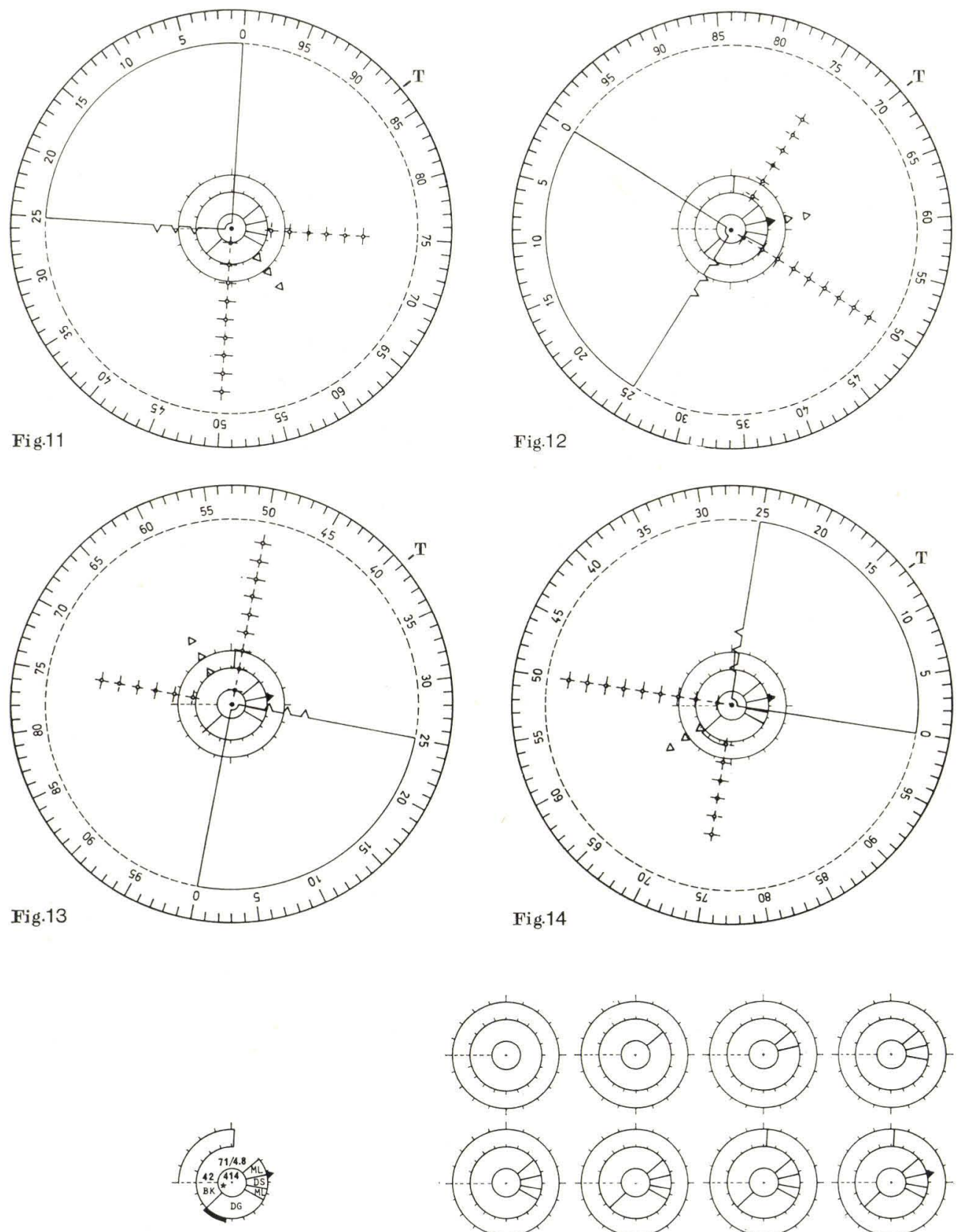

Fig.15
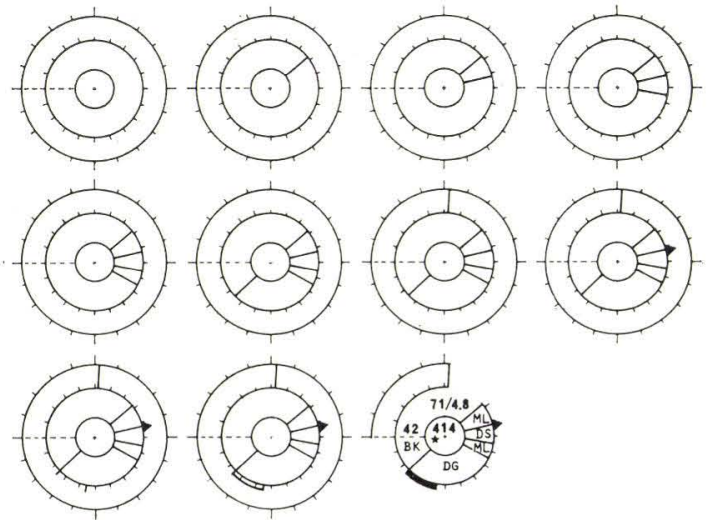

Fig.16 
Fig. 11. The contact at $87 \mathrm{~m}$ (bottom of hole) is drawn in circle No. 2 .

Fig. 11. Laggransen på $87 \mathrm{~m}$ placeres $i$ cirkel $\mathrm{nr} .2$ som boringens bund.

Fig. 12. The groundwater level is indicated at $8 \mathrm{~m}$ below surface (black triangle).

Fig. 12. Grundvandstanden placeres i $8 \mathrm{~m}$ under terran (sort trekant).

Fig. 13. The screened interval is indicated from $39-49 \mathrm{~m}$ below surface.

Fig. 13. Filteret placeres $i$ 39-49 $m$ under terran.

Fig. 14. The outer boundary of the symbol of the screened interval is drawn by placing a pen in the corresponding perforation of the row of perforations $E$ in fig. 4, using the template as a pair of compasses.

Fig. 14. Filtersignaturens ydre begransning tegnes ved at anbringe pennen $i$ det dertil beregnede hul $i$ hulrakke E på fig. 4 og benytte skabelonen som passer.

Fig. 15. Number of the well, symbols etc. are added, and the unused parts of the preprinted cyclogram are cut off before the adhesive film with the well-record-cyclogram is placed on the map.

Fig. 15. Symboler, tal m.v. anbringes, og den ikke benyttede del af det fortrykte cirkeldiagram bortskares, for det påklabes kortet.

Fig. 16. The successive construction of a well-record-cyclogram, as shown in figures 5-15.

Fig. 16. Den successive konstruktion af et cirkeldiagramprofil som vist i fig. 5-15. 


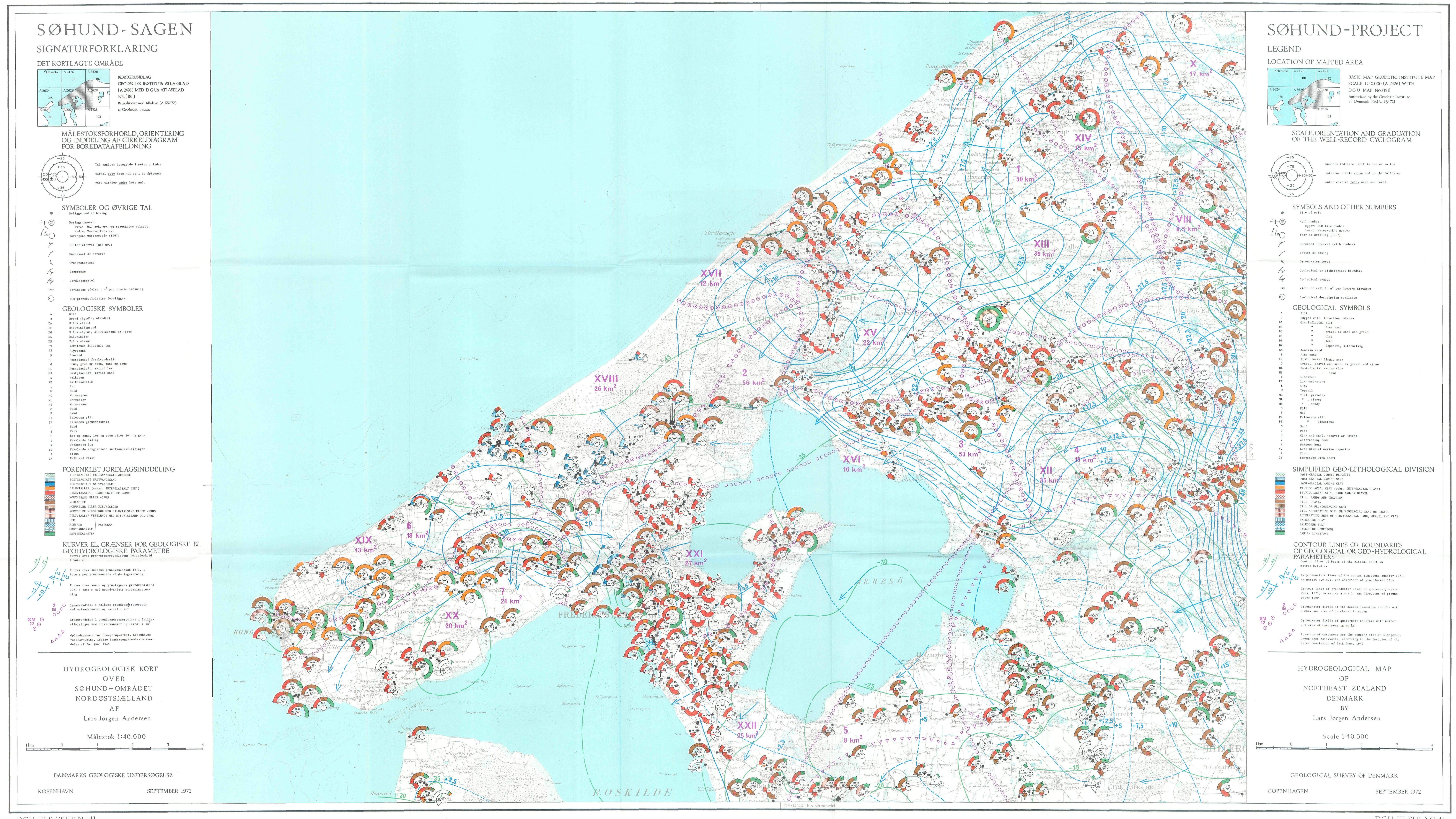

